\title{
The Pharmacological Effects of Bitter Melon
}

\author{
Ebru Ekizce and Husamettin Ekici* \\ Department of Pharmacology and Toxicology, Kirikkale University Faculty of Veterinary Medicine, Turkey
}

Submission: December 27, 2018; Published: January 04, 2019

*Corresponding author: Husamettin EKICI, Department of Pharmacology and Toxicology, Kirikkale University Faculty of Veterinary Medicine, 71450, Kirikkale, Turkey

\begin{abstract}
Plants have been used in alternative therapies of diseases since ancient times. In recent years, research has identified the benefits of a large number of plants used as conventional medicines. Bitter melon (Momordica charantia) has traditionally been milk-enhancing, laxative, antidiabetic, and antihelmintic as well as contraceptive, painful menstruation, eczema, gout failure, jaundice, abdominal pain, kidney stone, leprosy, hemorrhoids, pneumonia, psoriasis since ancient times. disease, rheumatism, fever and scabies, as well as many symptoms and diseases. In addition, recent studies have shown that it is effective against Helicobacter pylori in the treatment of peptic ulcer and colitis. Research has been shown to have an effect against many types of cancer (leukemia, lymphoma, choriocarcinoma, melanoma, breast cancer, skin tumors, etc.). With this study, it was aimed to be an auxiliary source for the study of this plant with the pharmacological evaluation of Bitter melon.
\end{abstract}

Keywords: Bitter melon; Phytotherapy; Antidiabetic effect; Anticancerogenic effect

\section{Introduction}

Especially in developing countries, which correspond to a large proportion of the world population, conventional drugs are used to solve medical problems. Recent studies have focused on the scientific evolution of traditional herbal medicines. Bitter melon is one of the plants used as an alternative in the treatment of medical problems [1,2].

\section{The health effects of Bitter melon}

Various plants and nutrients have been used in the treatment of diseases from past to present. Recently, the use of therapeutic properties of natural resources is increasing. Among the reasons for this situation; In some cases, synthetic drugs are insufficient and various side effects are detected. In addition, while synthetic drugs affect a single region, the herbal products can be more effective with their rich ingredients and they can be used by large masses because they are cheap and easily accessible $[3,4]$.

\section{Pharmacological Effects}

\section{Antidiabetic Effect}

Some clinical studies have shown that Bitter melon reduces glucose levels in the blood by improving glucose tolerance and decreases hemoglobin A1c levels in some type 2 diabetes patients $[5,6]$. In most of the studies, it is stated that the potency of glucose causes hypoglycemia by stimulating the use of glucose in the primary skeletal muscles. It has been found that the pancreas protects $\beta$ cells by inhibiting the absorption of glucose in the intestines and increases the release of insulin by suppressing the glucogenetic enzyme [7-10].

\section{Anticancerogenic Effect}

Remarkably, it has been shown to show anticarcinogenic activity against malignant tumors [11,12]. Many pre-clinical studies indicate that the extracts of Bitter melon or isolated compounds show an anticarcinogenic effect against lymphoid leukemia, lymphoma, breast, skin, prostate, colon, urinary bladder, pancreas and hodgking disease [13].

\section{Antioxidant Effect}

It is known that the damage caused by oxidative stress caused by the absence of free radicals in cells plays a causal role in the formation of cancer and similar disease states [14]. Research shows that the potent plant is a rich source of antioxidants and can potentially be useful against the harmful effects of free radicals [15]. In particular, the bark and seeds of the fruit are rich in phenolic compounds exhibiting strong anti-oxidant [16].

\section{Antiulcer Effect}

Extract prepared with fresh fruits and dried fruits mixed with olive oil or honey in Turkey is used for the treatment of peptic ulcer. It has been reported that Helicobacter pylori, which is responsible for the development of fruits as well as stomach and duodenal ulcers, prevents the growth of organisms [7].

\section{Effects on Skin Wounds}

It is stated that the cream gel and honey blended products obtained from the virgin fruit are beneficial in the external application of the skin wounds, tissue disorders and skin 
problems such as psoriasis, abscess and eczema [17]. In addition, it has been observed that regional Momordica charantia, which is applied in acute burns, has been found to be effective in maintaining the locos infiltration, collagen decolorization, vein, hair root and glandula sebaceous damage, and the maintenance of the number of vessels and epidermis thickness [18].

\section{Effect of Estradiol}

The changes in menopause and the decrease of estradiol (E2) hormone levels in the circulatory system, which causes the quality of life of the females, is decreased and replaced by estrone hormone. In experimental studies performed for this purpose, it was found that Bitter melon fruit serum estradiol, estrogen receptors increased ESR-1 and ESR-2 levels, histologically decreased neutrophil infiltration, and cell and collagen distribution returned to normal and epithelial cells were increased [19].

\section{Antimicrobial Effect}

Extracts of the pomegranate, especially the leaves, obtained with ethanol and methanol, have antimicrobial activity against many microorganisms such as Escherichia coli L, Salmonella paratypi L. and Shigella dysenterae L. It has been found that the phenolic compounds in the fruit of the pomegranate inhibit the enzymes in microorganisms and eliminate the harmful effects of microorganisms [17].

\section{Antiviral Effect}

Momordica charantia proteins inhibit the growth of HIV 1 virus in $\mathrm{T}$ cells, monocytes and virus-infected cells. It shows its effect by inhibiting HIV 1 inductase. It has been shown that the MRK29 protein obtained from fruit and seed is 50\% inhibited by HIV terstranskriptase. MRK29 reduces viral core protein HIV-1 infected cells by $82 \%$ and increases tumor necrosis factor (TNF) activity three-fold [20].

\section{Conclusion}

In recent studies, Bitter melon affects many systems thanks to its components and protein structure. It has been observed that the plant has a decrease in the formation of all organs such as breast, pancreas and colon. It has been reported that it is very common in the digestive system, diabetes mellitus and skin problems. It has also been shown to have antibacterial and antiviral effects. Studies show that the Bitter melon, which is commonly used in the world, is used effectively in public health as an alternative to chemical methods in treatment in our country. Therefore, it is thought that this fruit can be used in the treatment of veterinary medicine and human medicine with new researches on bioactive substances found in Bitter melon and studies on this subject should be supported.

\section{References}

1. Giron LM, Freire V, Alonzo A, Caceres A (1991) Ethnobotanical survey of the medicinal flora used by the Caribs of Guatemala. Journal of Ethnopharmacology 34: 173-187.
2. Lans C, Brown G (1998) Observations on ethnoveterinary medicines in Trinidad and Tobago. Preventive Veterinary Medicine 35: 125-142.

3. Jayasooriya AP, Sakono M, Yukizaki C, Kawano M, Yamamoto K, et al. (2000) Effects of Momordica charantia L. powder on serum glucose levels and various lipid parameters in rats fed with cholesterol-free and cholesterol-enriched diets. Journal of Ethnopharmacology 72: 331-336.

4. Vermani K, Garg S (2002) Herbal medicines for sexually transmitted diseases and AIDS. Journal of Ethnopharmacology 80: 49-66.

5. Dans AML, Villarruz MVC, Jimeno CA, Javelosa MAU, Chua J, et al. (2007) The effect of Momordica charantia capsule preparation on glycemic control in type 2 diabetes mellitus needs further studies. Journal of clinical epidemiology 60(6): 554-559.

6. Tsai CH, Chen ECF, Tsay HS, Huang, CJ (2012) Wild bitter gourd improves metabolic syndrome: a preliminary dietary supplementation trial. Nutrition Journal 11(1): 4.

7. Grover JK, Yadav SP (2004) Pharmacological actions and potential uses of Momordica charantia: a review. Journal of Ethnopharmacology 93: 123-132.

8. Joseph B, Jini D (2013) Antidiabetic effects of Momordica charantia (bitter melon) and its medicinal potency. Asian Pacific Journal of Tropical Disease 3(2): 93-102.

9. Leung L, Birtwhistle R, Kotecha J, Hannah S, Cuthbertson S (2009) Antidiabetic and hypoglycaemic effects of Momordica charantia (bitter melon): a mini review. British Journal of Nutrition 102(12): 1703-1708.

10. Yin J, Zhang H, Ye J (2008) Traditional Chinese medicine in treatment of metabolic syndrome. Endocrine, Metabolic \& Immune DisordersDrug Targets (Formerly Current Drug Targets-Immune, Endocrine \& Metabolic Disorders) 8(2): 99-111.

11. Kaur M, Deep G, Jain AK, Raina K, Agarwal C, et al. (2013) Bitter melon juice activates cellular energy sensor AMP-activated protein kinase causing apoptotic death of human pancreatic carcinoma cells. Carcinogenesis, 34(7): 1585-1592.

12. Hsiao PC, Liaw CC, Hwang SY, Cheng HL, Zhang LJ, et al. (2013) Antiproliferative and hypoglycemic cucurbitane-type glycosides from the fruits of Momordica charantia. Journal of agricultural and food chemistry, 61(12): 2979-2986.

13. Fang EF, Ng TB. (2011) Bitter gourd (Momordica charantia) is a cornucopia of health: a review of its credited antidiabetic, anti-HIV, and antitumor properties. Current molecular medicine 11(5): 417-436.

14. Wondrak GT (2009) Redox-directed cancer therapeutics: molecular mechanisms and opportunities. Antioxidants \& redox signaling 11(12): 3013-3069.

15. Raina K, Kumar D, Agarwal R (2016) Promise of bitter melon (Momordica charantia) bioactives in cancer prevention and therapy. In Seminars in cancer biology. 40:116-129.

16. Horax R, Hettiarachchy N, Chen P (2010) Extraction, quantification, and antioxidant activities of phenolics from pericarp and seeds of bitter melons (Momordica charantia) harvested at three maturity stages (immature, mature, and ripe). Journal of agricultural and food chemistry 58(7): 4428-4433.

17. Elibal B (2009) Kanola Yağından Kudret Narı Yağ Asitleri (klna) İle Yapılandırılmış Yağ Üretimi Ve Reaksiyon Koşullarının Optimizasyonu (Doctoral dissertation, Graduate School of Natural and Applied Sciences).

18. Tepe F (2016) Comparison of the topical momordica charantia (bitter melon) treatment and the effects of emergency treatment methods on the wound healing in experimental Doctoral dissertation, Ege University, Turkey. 
19. Akpınar H (2013) The effect of Bitter melon (Momordica charantia) on the gene levels of estrogene receptors ESR1 and ESR2 with on oxidative DNA damage. Doctoral dissertation, Graduate School of Health Sciences Marmara University, Turkey.
20. Baser HC (2012) Kudret narı (Momordica charantia L.). Bağbahçe 42: 28-29

\section{Your next submission with Juniper Publishers will reach you the below assets}

- Quality Editorial service

- Swift Peer Review

- Reprints availability

- E-prints Service

- Manuscript Podcast for convenient understanding

- Global attainment for your research

- Manuscript accessibility in different formats

( Pdf, E-pub, Full Text, Audio)

- Unceasing customer service

Track the below URL for one-step submission https://juniperpublishers.com/online-submission.php 